\title{
INTERVENSI UNTUK MENGURANGI DEPRESI POSTPARTUM
}

\author{
Tetti Solehati*, Aat Sriati, Cecep Eli Kosasih \\ Fakultas Keperawatan, Universitas Padjadjaran, Jl. Raya Bandung - Sumedang No.KM. 21, Hegarmanah, Kec. \\ Jatinangor, Kabupaten Sumedang, Jawa Barat, Indonesia 45363 \\ *tetti.solehati@unpad.ac.id
}

\begin{abstract}
ABSTRAK
Depressi Postpartum sering terjadi setelah melahirkan yang terjadi akibat adanya Riwayat gangguan dysphoric premenstrual sebelumnya, stres psikososial, dan dukungan sosial yang tidak memadai bagi ibu. Diperlukan intervensi untuk mencegah terjadinya depressi postpartum selama masa kehamilan, persalinan dan postpartum. Tujuan penelitian untuk mengetahui intervensi yang efektif dalam mencegah depresi post partum. Metode pencarian literature secara komprehensif dilakukan melalui Database EBSCO ditermukan 6.620 artikel dan sciendierect 21.163 artikel. Setelah melakukan penyaringan, diperolah 5 artikel yang memenuhi syarat. Hasil penelitian diperoleh bahwa terdapat lima intervensi yang dapat dilakukan untuk mengurangi kondisi depresi postpostpartum, antara lain: terapi pendidikan terstruktur, terapi thought stopping, terapi managing our mood (MOM), terapi relaksasi musik, dan intervensi pemberian suplemen zat besi. Kesimpulan berdasarkan hasil penelitian bahwa terapi pendidikan terstruktur, terapi thought stopping, terapi managing our mood (MOM), terapi relaksasi music, dan intervensi pemberian suplemen zat besi efektif dalam mencegah atau mengurangi depresi post partum.
\end{abstract}

Kata kunci: depresi postpartum, intervensi, pencegahan

\section{INTERVENTION TO REDUCE POST-PARTUM DEPRESSION}

\begin{abstract}
Postpartum depression often occurs after childbirth, which results from a history of previous premenstrual dysphoric disorders, psychosocial stress, and inadequate social support for the mother. Interventions are needed to prevent postpartum depression during pregnancy, childbirth and postpartum. The aim of the study was to find out effective interventions in preventing post-partum depression. A comprehensive literature search was carried out through the EBSCO Database found 6,620 articles and 21,163 ScienceDirect articles. After screening, 5 articles were obtained which fulfilled the requirements. There were five interventions that could be carried out to reduce post-postpartum depression, including structured educational therapy, thought stopping therapy, managing our mood (MOM) therapy, music relaxation therapy, and iron supplementation interventions. This study can be concuded that structured educational therapy, thought stopping therapy, managing our mood (MOM) therapy, music relaxation therapy, and iron supplementation interventions are effective in preventing or reducing post-partum depression.
\end{abstract}

Keywords: intervention, prevention, post-partum depression

\section{PENDAHULUAN}

Melahirkan bayi menggembirakan bagi keluarga terutama seorang ibu, meskipun demikian seringkali menimbulkan rasa ketidak nyamanan karena adanya nyeri ataupun timbulnya masalah psychologi yang ditandai dengan adanya gejala kecemasan dan depresi. Tingkat Depresi Postpartum yang dilaporkan di negara berkembang di Asia masih tinggi berkisar antara 17\% hingga 48\% (Nurbaeti, Deoisres, \& Hengudomsub, 2019). Demikian juga di Indonesia, hal ini masih menjadi masalah. Data Riset Kesehatan Dasar (Riskesdas) tahun 2013 menunjukan bahwa prevalensi gangguan mental emosional dengan gejala-gejala kecemasan dan depresi sebesar sebesar $6 \%$ atau sekitar 14 juta orang dari populasi penduduk Indonesia (Kemenkes, 2016). Pada sebuah penelitian di Jakarta Selatan, prevalensi Depresi Postpartum yang menggunakan skor cut-o EPDS ((Edinburgh Post-partum Depression Scale) 12 atau lebih, ditemukan 19,88\% ( $\mathrm{n}=33)$. Angka tersebut cukup besar dan berdampak pada ibu dan bayinya apabila ibu tidak bisa menangani masalah pada periode Postpartum tersebut.

Pada periode Postpartum, ada ibu yang bisa menyesuaikan diri dengan baik, tetapi ada sebagian yang tidak berhasil menyesuaikan diri bahkan mengalami gangguan-gangguan psikologis (Mansur, 2014). Masa postpartum merupakan masa krisis bagi ibu, suami, dan 
keluarga; karena perubahan fisik, psikologis, dan struktur keluarga membutuhkan proses adaptasi. Adaptasi psikologis postpartum diklasifikasikan menjadi tiga fase yaitu: fase menerima, menahan, dan melepaskan. Tiga fase tersebut akan terlewati dengan baik jika ibu postpartum didukung secara sosial oleh orang-orang di sekitarnya. Ibu postpartum yang gagal dalam melewati tiga fase itu akan menghadapi postpartum blues (Laela, 2018).

Periode Postpartum harus dianggap sebagai waktu yang rentan untuk terjadinya gangguan psikologis. Pada hari pertama pasca-partum, tubuh ibu sering merasa tidak nyaman, ditambah lagi dengan adanya tugas perawatan rutin bayi yang mengganggu istirahat malam ibu, terutama setelah kelahiran anak pertama (Organization, 1996). Sebuah penelitian ilmiah menunjukkan bahwa gejala postpartum blues akan memuncak pada hari ketiga dan kelima, ketika perubahan hormon terbesar (penurunan kadar progresteron, kortisol, dan estrogen, serta peningkatan kadar prolaktin) terjadi (Kaźmierczak, Gebuza, Banaszkiewicz, Mieczkowska, \& Gierszewska, 2017). Fenomena ini terjadi pada 10\%-20\% kasus. Dalam klasifikasi DSM-IV dan ICD-10, postpartum blues muncul dalam beberapa minggu pertama setelah melahirkan. Gejala dasar depresi menurut ICD-10 adalah suasana hati yang tertekan, kehilangan minat dan kepuasan, dan kekurangan energi. Gejala lain yang muncul adalah saat menyusui bayi di malam hari, kesulitan tidur, perhatian yang berlebihan terhadap kesehatan anak, perasaan bersalah, pikiran kematian yang berulang, serta rencana atau upaya bunuh diri (Kaźmierczak et al., 2017).

Masalah pada periode post partum tersebut dapat berkurang dengan adanya dukungan sosial yang memadai dan dukungan dari pemberi perawatan yang terlatih selama masa kehamilan, persalinan dan periode Postpartum. Pada masa postpartum terjadi proses penyembuhan dan perubahan, serta penyesuaian terhadap hadirnya anggota keluarga baru (Mitayani, 2009), sehingga memerlukan adaptasi psychologis bagi ibu untuk mengatasi masalah pada masa post partum.
Berdasarkan masalah yang sering terjadi pada periode post partum tersebut, kami akan mengulas intervensi yang bisa dijadikan sebagai referensi untuk meningkatkan pengetahuan dan menjadi referensi baru dalam memberikan intervensi untuk dapat diaplikasikan kepada penderita Depresi Postpartum. Melalui penelitian ini kami ingin menginvestigasi intervensi yang efektif dalam mencegah depresi post partum.

\section{METODE}

Tinjauan literatur dilakukan berdasarkan data empiris yang dipublikasikan secara umum dari tahun 2009 hingga tahun 2019 atau kurang lebih selama 10 tahun kebelakang. Metode yang digunakan untuk melakukan tinjauan literatur dengan pencarian melalui database elektronik di internet setelah merumuskan PICO. Kata kunci yang digunakan (keyword) yang digunakan untuk mencari jurnal adalah P: postpartum blues, I: cognitive therapy, $\mathrm{C}:-, \mathrm{O}$ : decrease depression stage. Database yang digunakan dalam pencarian literatur diantaranya EBSCO dan Science Direct.

Hasil pencarian di EBSCO dengan kata kunci postpartum depression, ditemukan 6.620 artikel. Melalui Science Direct dengan kata kunci postpsrtum depression ditemukan 21.163 artikel. Lalu dari kedua database tersebut setelah duplikat di hapus, jumlah artikel yang ditemukan sebanyak 6.620. Setelah dilakukan screening, kata kunci ditambahkan dengan "cognitive therapy" ditemukan 10 artikel dan 6.615 artikel dikecualikan.

Dari banyaknya artikel yang kami temukan, cara kami untuk menemukan artikel yang tepat adalah dengan melihat jenis penelistian dari setiap artikel yang kami temukan. Berdasarkan kata kunci intervensi "cognitive therapy", kelompok kami menilai kelayakan dari setiap artikel, yaitu dengan kriteria jenis penelitian yang dilakukan adalah quasi-experiment/RCT. Setelah itu kami menginklusikan penelitian yang kami dapat sesuai kriteria inklusi yang kami sebutkan sebelumnya. Berdasarkan pencarian tersebut kami memilik 5 artikel yang akan dianalisis. 


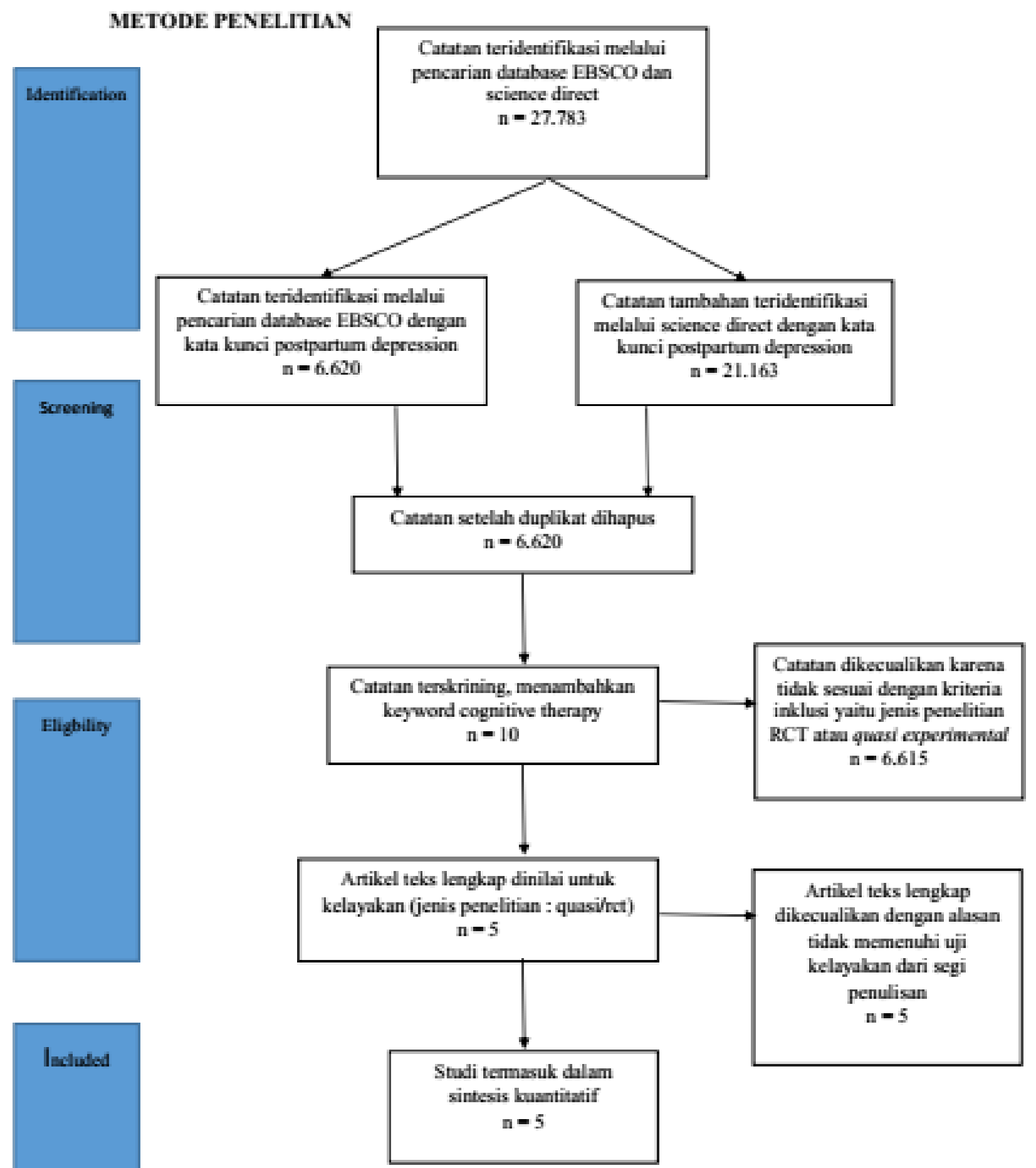

\section{HASIL}

Setelah dilakukan tinjauan literatur, kami menemukan beberapa intervensi yang dapat dilakukan untuk mengurangi kondisi depresi postpostpartum, antara lain terapi pendidikan terstruktur, terapi thought stopping, terapi managing our mood (MOM), terapi relaksasi musik, dan intervensi pemberian suplemen zat besi

\section{Terapi Pendidikan Terstruktur}

Penelitian Terapi Pendidikan Terstruktur dilakukan oleh Top et all (2016) berjudul Effectiveness of Structured Education in 
Reduction of Postpartum Depression Scores: A Quasi-Experimental Study, desain penelitian Quasi-experimental dengan pre dan post test dan group terkontrol, bertujuan untuk mengembangkan materi pendidikan dan mengevaluasi efektivitas pendidikan terstruktur dengan menggunakan materi pendidikan dalam pengurangan gejala postpartum depression pada wanita. Sample dalam penelitian berjumlah 103 wanita Turki (52 group intervensi dan 51 group kontrol). Teknik sampling yang digunakan untuk mengambil sampel adalah Convenience sampling (Top \& Karaçam, 2016).

Para wanita dalam kelompok intervensi dikunjungi dua kali di rumah mereka. Kunjungan pertama dilakukan dalam tiga sesi. Pada sesi pertama, perempuan menyelesaikan alat pengumpulan data (kuesioner Multidimensional Scale of Perceived Social Support (MSPSS) Edinburgh Postnatal Depression Scale (EPDS) dan kemudian istirahat 10 menit d. Dalam sesi kedua dan ketiga, para wanita ditawari pendidikan 60 menit dengan istirahat 10 menit oleh penulis pertama. Materi dibuat satu-satu menggunakan presentasi lisan dengan bahan materi yang terstruktur dan metode diskusi. Materi pendidikan diberikan kepada para wanita yang mengikuti program pendidikan. Kunjungan pertama selesai dalam waktu sekitar 90-100 menit. Dua bulan kemudian, kunjungan rumah kedua dilakukan sekitar 10-15 menit dan EPDS diselesaikan oleh para wanita.

Hasil penelitian menunjukan bahwa skor median $(8,0 \pm 4,8)$ dari kelompok intervensi sebelum diberikan pendidikan secara signifikan lebih tinggi dari skor $(4,0 \pm 3,0)$ yang diperoleh setelah pendidikan $(\mathrm{p}=0,000)$, sedangkan skor median $(6,0 \pm 6,0)$ dari kelompok kontrol sebelum pendidikan lebih rendah dari skor $(10.0 \pm 4.0)$ yang diperoleh setelah pendidikan $(\mathrm{p}=0.000)$.

\section{Terapi Thought Stopping}

Penelitian Laela dkk (2018) yang berjudul Thought stopping and supportive therapy can reduce postpartum blues and anxiety parents of premature babies, dengan desainenelitian quasieksperimental dengan control grup pretest posttest, bertujuan untuk mengidentifikasi pengaruh thought stopping dan terapi suportif pada postpartum blues dan kecemasan pada orang tua dengan bayi prematur. Jumlah Sampel 62 peserta dengan teknik sampling berupa convenience sampling. Instrument yang digunakan untuk mengukur hasil adalah HARS (Hamilton Anxiety Rating Scale) dan EPDS
(Edinburgh Post-partum Depression Scale) (Laela $\&$ Keliat, 2018).

Hasil penelitian menunjukkan bahwa kecemasan orang tua dari bayi prematur yang dirawat dengan intervensi keperawatan dan Terapi Thought Stopping menurun dari kecemasan tinggi ke sedang $(14,46)$ dan kecemasan orang tua yang tidak diobati dengan Terapi Thought Stopping menurun dari kecemasan tinggi ke sedang $(12,32)$.

\section{Terapi Managing Our Mood (MOM)}

Penelitian Strongest Families ${ }^{\mathrm{TM}}$ Managing Our Mood (MOM): a randomized controlled trial of a distance intervention for women with postpartum depression dilakukan oleh Wozney et all (2017) dengan jenis penelitian Randomized controlled trial, bertujuan untuk menyelidiki apakah intervensi yang diberikan jarak dapat secara signifikan mengurangi depresi postpartum ringan hingga sedang pada ibu. Sampel pada penelitian ini adalah ibu dengan depresi postpartum $(n=62)$ secara acak ditugaskan untuk intervensi atau perawatan komunitas standar. Peserta yang menerima intervensi mendapatkan buku informasi perilaku kognitif 12-sesi yang didukung dengan dukungan pelatihan berbasis telepon (Wozney et al., 2017). MOM adalah 12 sesi, intervensi berbasis perilaku kognitif untuk depresi postpartum. Hasil menunjukan banyak ibu-ibu melaporkan kepuasan yang tinggi dengan intervensi jarak program MOM ini.

\section{Terapi Relaksasi Musik}

Penelitian yang dilakukan oleh Dabas et all (2019), berjudul impact of audio assisted relaxation technique on stress, anxiety and milk output among postpartum mothers of hospitalized neonates: A randomized controlled trial bertujuan untuk mengkaji dampak teknik relaksasi yoga dengan bantuan audio terhadap stres, kecemasan, dan produksi ASI dari ibu postpartum dengan neonatus yang dirawat di NICU. Penelitiannya menggunakan Randomized controlled trial. Sampel dalam penelitian ini adalah 50 ibu postpartum yang memenuhi kriteria inklusi dan setuju menjadi peserta, terbagi menjadi dua yaitu kelompok eksperimen $(\mathrm{n}=25)$ dan kelompok kontrol $(n=25)$. Instrument yang digunakan pada pengumpulan data awal menggunakan lembar demografi pretest, Skala Stres Orang Tua terstandardisas yaitu: Skala NICU, dan Skala Skrining Kecemasan Perinatal.

Teknik relaksasi yang diberikan melalui audio berdurasi 30 menit, dikembangkan di bawah bimbingan terapis yoga, termasuk pernapasan 
dalam (5 menit), Suksham Vyayam (8 menit), Anulom-Vilom (5 menit), Brahmari (5 menit), Relaksasi Otot Progresif (PMR) (5 menit), dan dalam bernafas (2 menit). Teknik relaksasi diperlihatkan dan diberikan kepada ibu postpartum dari kelompok eksperimen pada hari pendaftaran oleh terapis yoga dan peneliti. Teknik relaksasi dimainkan menggunakan laptop di ruang yang cukup terisolasi di bangsal pascanatal antara pukul 6: 00-6: 30 malam, dan ibu postpartum mengikuti instruksi dalam kelompok kecil dalam posisi duduk di kursi di bawah pengawasan peneliti selama 10 hari berturut-turut. Ibu-ibu pascanatal diizinkan untuk mengambil makanan ringan 2 jam sebelum sesi. Mereka juga diminta untuk tidak membahas intervensi dengan ibu postpartum lain yang dirawat di bangsal. Kepatuhan ibu postpartum dengan teknik relaksasi dipastikan dengan mempertahankan catatan. Selama periode yang sama, kelompok kontrol terus menerima perawatan rutin. Mereka ditanyai tentang praktik teknik relaksasi apa pun oleh peneliti. Tidak ada kejadian seperti itu yang dilaporkan oleh ibu postpartum dari kelompok kontrol. Hasil penelitian menemukan bahwa ada pengurangan signifikan yang diamati pada stres ibu dan skor kecemasan $(\mathrm{p} \leq 0,05)$ dan peningkatan produksi susu $(\mathrm{p} \leq 0.05)$ pada kelompok eksperimen dibandingkan dengan kelompok kontrol (Dabas, Joshi, Agarwal, Yadav, \& Kachhawa, 2019).

\section{Intervensi Pemberian Suplemen Zat Besi}

Penelitian yang dilakukan oleh Sheikh et all (2017), dengan design randomized double-blind placebo-controlled trial, bertujuan untuk mengevaluasi penggunan sumplemen zat besi dini pada ibu yang tidak anemia dengan depresi postpartum. Populasi pada penelitian ini $260 \mathrm{ibu}$ postpartum yang melahirkan di RS Pendidikan Vali-Asr dari November 2013 - September 2014, dengan Sampel 70 ibu dengan depresi postpartum yang memenuhi kriteria inklusi yang dibagi menjadi kelompok intervensi dan kelompok kontrol masing-masing sebanyak 35 peserta. Instrument yang digunakan untuk mengukur hasil adalah EPDS (Edinburgh Post-partum Depression Scale).

Para peserta dalam kelompok intervensi menerima tablet besi sulfat yang mengandung unsur besi $50 \mathrm{mg}$ sekali sehari, sedangkan kelompok kontrol menerima plasebo sekali sehari. Plasebo terdiri dari tablet selulosa yang identik dalam bentuk dan warna dengan tablet besi sulfat. Setelah 6 minggu menjadi peserta penelitian, para peserta dikunjungi oleh psikiater yang sama dan diminta untuk mengulang EPDS. Terakhir, sampel darah tambahan diperoleh untuk menentukan simpanan zat besi dan indeks hematologi. Selain itu, jangka waktu ditetapkan pada 6 minggu, mengingat bahwa minggu-minggu pertama pascakelahiran mewakili waktu yang krusial dalam membentuk hubungan ibu-bayi dan peningkatan depresi postpartum selama periode waktu ini dapat secara signifikan mengurangi efek buruknya. Hasil penelitiannya menunjukan bahwa terdapat penurunan skor EPDS yang signifikan pada kelompok intevensi setelah diberikan suplemen zat besi $(\mathrm{p}<0,001)$ sedangkan pada kelompok control tidak ditemukan perubahan yang signifikan $(\mathrm{p}=0,13)$ (Sheikh, Hantoushzadeh, Shariat, Farahani, \& Ebrahiminasab, 2017). Pemberian supplement besi terbukti dalam menurunkan tingkat depresi pada ibu dengan depresi postpartum. Selain itu, di dalam penelitian ini, kekurangan zat besi tanpa anemia terdeteksi pada $37,1 \%$ ibu dengan depresi postpartum.

\section{PEMBAHASAN}

\section{Terapi Pendidikan Terstruktur}

Penelitian Terapi Pendidikan Terstruktur efektif dalam mengurangi skor depresi pascapersalinan dan jumlah wanita yang mengalami depresi. Studi ini menunjukan bahwa pendidikan terstruktur yang ditawarkan oleh perawat efektif untuk mengurangi skor depresi pascapersalinan dan jumlah wanita yang mengalami depresi. Dalam penelitian ini, kelompok intervensi dan kontrol dibandingkan dalam hal beberapa variabel yang dilaporkan menyebabkan risiko tinggi depresi postpartum. hal ini sejalan dengan Hutagaol (2010) menunjukan bahwa setelah diberikan intervensi edukasi menunjukkan penurunan depresi postpartum (Hutagaol, 2010). Materi edukasi yang di berikan secara personal melalui kunjungan rumah terbukti efektif bagi ibu post partum karena ada tindak lanjut pembelajaran yang telah diberikan selama di rumah sakit, serta dapat memandirikan ibu post partum dan keluarganya dalam merawat ibu dan bayinya (Runiari, 2005).

\section{Terapi Thought Stopping}

Metode Intervensi thought stopping and supportive therapy terbukti berhasil dalam menurunkan tingkat kecemasan orang tua dari bayi prematur yang dirawat dengan intervensi keperawatan. Hasil ini menunjukkan bahwa adanya penurunan pada blues postpartum dan kecemasan orang tua dari kelompok bayi prematur yang mendapatkan intervensi terapi relaksasi dengan thought stopping dan terapi supportif dibandingkan dengan yang hanya mendapatkan 
intervensi keperawatan. Hasil penelitian menunjukkan bahwa penghentian berpikir dan terapi suportif mampu mengurangi rasa sakit pasca persalinan dan kegelisahan orang tua dari bayi premature dua kali lebih besar daripada hanya intervensi keperawatan. Hasil uji menunjukkan bahwa setelah dilakukannya intervensi keperawatan, berhenti berpikir dan terapi suportif, ada yang normal dan nilai blues postpartum menurun dari positif postpartum blues ke postpartum blues negatif / normal.

Penurunan tingkat kecemasan dalam penelitian ini sejalan dengan hasil penelitian yang dilakukan oleh Agustarika (2009) yang mengatakan bahwa kecemasan klien yang mendapatkan Terapi Thought Stopping terapi penghentian mampu mengurangi tingkat kecemasan dan meningkatkan pertahanan diri individua (Agustarika, 2009). Penelitian lain juga dari Naikare et al. (2015) menghasilkan bahwa teknik penghentian pemikiran mampu mengendalikan tingkat stres pekerja industry (Naikare et al., 2015). Berdasarkan data di atas, intervensi keperawatan dan Terapi Thought Stopping mampu menurunkan postpartum blues dan kecemasan orang tua pada bayi prematur.

\section{Terapi Managing Our Mood (MOM)}

Metode intervensi MOM berpengaruh dalam peningkatan kepuasan ibu sehingga menurunkan tingkat kecemasan ibu. Hasil kepuasan MOM mirip dengan studi Keluarga Terkuat lainnya (McGrath et al., 2011; Sourander et al., 2016). Selain itu, analisis multivariat dari 34 studi yang dilakukan oleh Gellaty et all, yang memberikan bukti yang jelas tentang keunggulan intervensi 'dipandu' untuk depresi dibandingkan program swadaya murni dan menyarankan perawatan yang dipersonalisasi dengan manfaat tambahan dari fleksibilitas penjadwalan mungkin menjadi moderator utama (Gellatly et al., 2007). Temuan kami menunjukkan bahwa intervensi berbasis telepon dan terlatih tidak hanya bersifat rahasia, nyaman dan tidak menstigmatisasi untuk ibu tetapi mengurangi hambatan perawatan kesehatan seperti aksesibilitas karena perjalanan dan geografi. Peserta mengalami kesuksesan yang lebih besar semakin mereka berinteraksi dengan komponen pelatih intervensi.

Intervensi MOM terdiri dari 12 sesi, intervensi berbasis perilaku kognitif untuk depresi postpartum. Setelah itu, program ini diuji coba dengan 11 ibu untuk memastikan kegunaan. Umpan balik dari peserta selama uji coba dimasukkan ke dalam program sebelum RCT ini.
Lalu peserta diacak, setelah diacak, peserta dikirim paket berisi buku pegangan dan video yang sesuai dan brosur informasi pasangan / pendamping tentang depresi postpartum. video tersebut menampilkan segmen tiga ibu (aktor amatir) yang menceritakan kisah mereka masingmasing tentang depresi postpartum yang berkaitan dengan setiap sesi buku pegangan. Peralatan pemutar video dipinjamkan kepada peserta tanpa biaya sesuai kebutuhan. Untuk menyelesaikan intervensi, peserta diminta untuk meninjau setiap sesi dalam buku pegangan ini setiap minggu (ada fleksibilitas untuk memperhitungkan peristiwa hidup), menonton sesi video dan menyelesaikan serangkaian latihan. Peserta menerima panggilan telepon mingguan dari pelatih pribadi pada waktu yang nyaman (mis. Hari, malam, malam). Jika perlu, pembinaan panggilan dibagi menjadi dua bagian untuk mengakomodasi kebutuhan orang tua. Isi panggilan pelatihan dipatuhi skrip manual dengan tujuan yang pasti untuk meninjau kemajuan, pemecahan masalah, mendorong perolehan keterampilan dan memperkenalkan tema di sesi mendatang.

\section{Terapi Relaksasi Musik}

Terapi relaksasi music yang diberikan melalui audio berhasil dalam menurunkan stres ibu dan skor kecemasan. Dalam penelitian ini, teknik relaksasi yang dipadukan yoga terbukti efektif dalam mengurangi stres dan kecemasan ibu postpartum dari kelompok eksperimen. Hal ini terjadi karena musik disinyalir memengaruhi sistem limbik diotak, dimana stimulus suara musik di sistem limbik tersebut akan memanggil memori atau kenangan yang mendalam bagi seseorang sehingga mengakibatkan terjadinya perubahan mood pada orang yang mendengarkan musik tersebut (Chan, Chan, Mok, \& Kwan Tse, 2009). Hal ini sejalan dengan penelitian Suryani (2011) pada ibu primipara yang diberi terapi musik dimana terjadi penurunan skor kejadian postpartum blues (Manurung, Lestari, Wiradwiyana, Karma, \& Paulina, 2011). Selain itu dalam penelitian ini, teknik relaksasi berbantuan audio telah membantu para ibu dalam meningkatkan produksi ASI mereka, yang sejalan dengan berbagai penelitian di mana terapi musik, relaksasi otot progresif, dan terapi yoga juga menyebabkan peningkatan produksi ASI (Karbandi et al., 2017; Keith, Weaver, \& Vogel, 2012).

\section{Intervensi Pemberian Suplemen Zat Besi}

Metode intervensi dengan menggunakan sumplemen zat besi dini pada ibu yang tidak anemia dengan depresi postpartum berpengaruh 
dalam menurunkan skor EPDS. Pemberian supplement besi terbukti dalam menurunkan tingkat depresi pada ibu. Suplementasi zat besi dini secara signifikan meningkatkan simpanan zat besi dan menurunkan tingkat defisiensi besi pada ibu-ibu ini. Khususnya, suplementasi zat besi pada ibu dengan depresi postpartum dikaitkan dengan penurunan skor epds yang signifikan dan tingkat peningkatan $42,8 \%$ untuk depresi postpartum. selain itu, ada hubungan yang signifikan antara depresi postpartum lanjutan dan kadar feritin yang lebih rendah pada 7 minggu pascapersalinan. Pada penelitian ini, defisiensi besi tanpa anemia secara bermakna dikaitkan dengan kelanjutan depresi postpartum. Hal ini sejalan dengan temuan Shariatpanaahi et al. (2007) dalam sebuah studi pada wanita yang tidak hamil, di mana penurunan kadar feritin sebelum terjadinya anemia secara signifikan terkait dengan depresi (Shariatpanaahi, Shariatpanaahi, Moshtaaghi, Shahbaazi, \& Abadi, 2007). Demikian pula, Albacar et al. (2011) dan Beard et al. (2005) menilai hubungan antara depresi postpartum dan kadar feritin postpartum pada 48 jam dan 10 minggu setelah persalinan dalam dua studi terpisah, menyimpulkan bahwa kadar feritin yang rendah setelah persalinan secara bermakna dikaitkan dengan depresi postpartum dan, pada akhirnya, besi memainkan peran penting dalam patofisiologi depresi postpartum (Albacar et al., 2011; Beard et al., 2005).

\section{SIMPULAN}

Terdapat lima intervensi untuk mengurangi serta menurunkan kondisi depresi postpostpartum diantaranya terapi pendidikan terstruktur, terapi thought stopping, terapi managing our mood (MOM), terapi relaksasi music, dan intervensi pemberian suplemen zat besi yang efektif dalam mencegah atau mengurangi depresi post partum

Keberhasilan pelaksanaan penelitian ini tidak terlepas dari peran enumerator seperti Febiola N, Widy MJ, M Rusydan S, Afni FT, Nazla FN, Indah S, Nindy SR, Syafira D, Epi R, Azka A. Siti NH.

\section{DAFTAR PUSTAKA}

Agustarika, B. (2009). Pengaruh terapi thought stopping terhadap ansietas klien dengan gangguan fisik di RSUD Kabupaten Sorong $=$ The influence of thought stopping theraphy to the client anxiety who suffer physical illness in Sorong General Hospital.

Albacar, G., Sans, T., Martín-Santos, R., GarcíaEsteve, L., Guillamat, R., Sanjuan, J., Arija,
V. (2011). An association between plasma ferritin concentrations measured $48 \mathrm{~h}$ after delivery and postpartum depression. Journal of affective disorders, 131(1-3), 136-142.

Beard, J. L., Hendricks, M. K., Perez, E. M., Murray-Kolb, L. E., Berg, A., VernonFeagans, L., . . . Tomlinson, M. (2005). Maternal iron deficiency anemia affects postpartum emotions and cognition. The Journal of nutrition, 135(2), 267-272.

Chan, M. F., Chan, E. A., Mok, E., \& Kwan Tse, F. Y. (2009). Effect of music on depression levels and physiological responses in community-based older adults. International Journal of Mental Health Nursing, 18(4), 285-294.

Dabas, S., Joshi, P., Agarwal, R., Yadav, R. K., \& Kachhawa, G. (2019). Impact of audio assisted relaxation technique on stress, anxiety and milk output among postpartum mothers of hospitalized neonates: A randomized controlled trial. Journal of Neonatal Nursing, 25(4), 200-204.

Gellatly, J., Bower, P., Hennessy, S., Richards, D., Gilbody, S., \& Lovell, K. (2007). What makes self-help interventions effective in the management of depressive symptoms? Meta-analysis and meta-regression. Psychological medicine, 37(9), 1217-1228.

Hutagaol, E. T. (2010). Efektivitas intervensi edukasi pada depresi postpartum. Fakultas Ilmu Keperawatan. Universitas Indonesia: Depok, Jakarta.

Karbandi, S., Hosseini, S. M., Hosseini, S. A., Sadeghi, F., Hesari, M., \& Masoudi, R. (2017). Evaluating the effectiveness of using a progressive muscle relaxation technique on the self-efficacy of breastfeeding in mothers with preterm infants. journal of nursing research, 25(4), 283-288.

Kaźmierczak, M., Gebuza, G., Banaszkiewicz, M., Mieczkowska, E., \& Gierszewska, M. (2017). Mood disorders after childbirth. Polish Annals of Medicine, 24(2), 111-116.

Keith, D. R., Weaver, B. S., \& Vogel, R. L. (2012). The Effect of music-based listening interventions on the volume, fat content, 
and caloric content of breast milk-Produced by mothers of premature and critically ill infants. Advances in Neonatal Care, 12(2), 112-119.

Kemenkes, R. (2016). Profil Kesehatan Republik Indonesia. Jakarta: Kementrian Kesehatan.

Laela, S., \& Keliat, B. A. (2018). Thought stopping and supportive therapy can reduce postpartum blues and anxiety parents of premature babies. Enfermeria clinica, 28, 126-129.

Manurung, S., Lestari, T. R., Wiradwiyana, B., Karma, A., \& Paulina, K. (2011). Efektivitas terapi musik terhadap pencegahan postpartum blues pada ibu primipara di Ruang Kebidanan RSUP Cipto Mangunkusumo Jakarta Pusat. Buletin Penelitian Sistem Kesehatan, 14(1 Jan).

McGrath, P. J., Lingley-Pottie, P., Thurston, C., MacLean, C., Cunningham, C., Waschbusch, D. A., . . Santor, D. (2011). Telephone-based mental health interventions for child disruptive behavior or anxiety disorders: randomized trials and overall analysis. Journal of the American Academy of Child \& Adolescent Psychiatry, 50(11), 1162-1172.

Mitayani. (2009). Asuhan Keperawatan Maternitas: Salemba Medika.

Naikare, V. R., Kale, P., Kanade, A. B., Mankar, S., Pund, S., \& Khatake, S. (2015). Thought stopping activity as innovative trend to deal with stresses. Journal of psychiatric nursing, 4(2), 63.

Nurbaeti, I., Deoisres, W., \& Hengudomsub, P. (2019). Association between psychosocial factors and postpartum depression in South Jakarta, Indonesia. Sexual \& Reproductive Healthcare, 20, 72-76.

Organization, W. H. (1996). Maternal and newborn health/safe motherhood unit, family and reproductive health. Care in normal birth: A practical guide. Geneva, Switzerland.

Runiari, N. (2005). Persepsi perawat, ibu postpartum dan keluarga tentang materi yang prioritas dan metode pemberian edukasi ibu postpartum di RSUD Fatmawati Tahun 2005. FIK-UI.

Shariatpanaahi, M. V., Shariatpanaahi, Z. V., Moshtaaghi, M., Shahbaazi, S., \& Abadi, A. (2007). The relationship between depression and serum ferritin level. European journal of clinical nutrition, 61(4), 532-535.

Sheikh, M., Hantoushzadeh, S., Shariat, M., Farahani, Z., \& Ebrahiminasab, O. (2017). The efficacy of early iron supplementation on postpartum depression, a randomized double-blind placebo-controlled trial. European journal of nutrition, 56(2), 901908.

Sourander, A., McGrath, P. J., Ristkari, T., Cunningham, C., Huttunen, J., LingleyPottie, P., . . Sinokki, A. (2016). Internetassisted parent training intervention for disruptive behavior in 4-year-old children: a randomized clinical trial. JAMA psychiatry, 73(4), 378-387.

Top, E. D., \& Karaçam, Z. (2016). Effectiveness of structured education in reduction of postpartum depression scores: a quasiexperimental study. Archives of psychiatric nursing, 30(3), 356-362.

Wozney, L., Olthuis, J., Lingley-Pottie, P., McGrath, P. J., Chaplin, W., Elgar, F., . . . Kennedy, J. (2017). Strongest Families ${ }^{\mathrm{TM}}$ Managing Our Mood (MOM): a randomized controlled trial of a distance intervention for women with postpartum depression. Archives of women's mental health, 20(4), 525-537. 